\title{
WHAT DOES PERISCOPE OFFER TO PROFESSIONAL AND CITIZEN REPORTERS? A SAMPLE STUDY FROM TURKEY
}

\author{
Gökmen Hakan KARADAĞ \\ Istanbul Aydin University, Turkey \\ gokmenkaradag@aydin.edu.tr
}

\begin{abstract}
"Live from the scene" has always been a key element for the broadcast media in attracting large audiences. This attraction, referred to as the sense of being there or the aspect of immediacy, has always led the broadcasting industry to embrace the latest technology. Digital technology provides great opportunities regarding live from the scene capabilities, not only for traditional media but also for new media. The term "live broadcast" in traditional media has been replaced by "live streaming" in new media. To date, the relationship of live streaming with concepts such as citizen journalism, new media, alternative media have been subject to several studies. As a popular live streaming application, what does Periscope offer to citizen journalism? What does Periscope mean for professional journalism? In this study, considering the answers to these questions, a quantitative content analysis was conducted on live streamings of a sample composed of professional and citizen reporters in Turkey which were streamed through Periscope application in a one-month period and conclusions were drawn regarding the potential that Periscope represents. Live streamings in the sample were categorized into old media format/new media format, inside/outside, breaking/non-breaking, by professional/by citizen, news/ non-news; and durations and audience shares of these categories were compared to conclude on the broadcast formats to which Periscope offers the highest potential.
\end{abstract}

Keywords: traditional media, live broadcast, new media, live streaming, Periscope, citizen journalism, social media, old media format, new media format

\section{PERISCOPE, PROFESYONEL VE YURTTAŞ HABERCILERE NE SAĞLIYOR? TÜRKIYYE'DEN BIIR ÖRNEKLEM ÇALIŞMASI}

ÖZ

Olay yerinden canlı yayın, televizyon kanalları için, geniş izleyici kitlelerini çekebilmek adına, her zaman çok önemli bir unsur olmuştur. Orada olma hissi veya anındalık boyutu olarak ifade edilen bu çekicilik, televizyon yayıncıllğı sektörünün, hep en son teknolojiyi benimsemesine yol açmıştır. Sayısal teknoloji sadece geleneksel medyaya değil yeni medyaya da olay yerinden canlı yayın konusunda büyük kolaylık sağlamıştır. Geleneksel medyadaki "canlı yayın" teriminin yerini yeni medyada, internetten canlı iletim olarak çevirebileceğimiz "live streaming" almıştır. İnternetten canlı iletim kavramının yurttaş gazeteciliği, yeni medya, alternatif medya gibi kavramlarla ilişkisi bugüne kadar çeşitli araştırmalara konu olmuştur. Popüler bir canlı iletim uygulaması olarak Periscope, yurttaş haberciliği için ne sağliyor? Periscope profesyonel habercilik için ne ifade ediyor? Bu çalışmada, bu soruların yanıtları 1şı̆̆ında, Türkiye'de profesyonel ve yurttaş habercilerden oluşturulan bir örneklemde, bir aylık zaman diliminde, Periscope uygulamasıyla yapılan canlı iletimlerin nicel içerik analizi yapılmış ve Persicope'un ifade ettiği potansiyel adına sonuçlar çıkarılmıştır. Örneklemdeki canlı iletimler; "eski medya formatı/yeni medya formatı, iç/dış, sıcak gelişme/sıcak gelişme değil, profesyonel haberci/ yurttaş haberci, haber içerikli/haber içerikli değil" gibi kodlamalarla kategorize edilmiş ve bu kategorilerin yayın süreleri ve izleyici sayıları karşılaştırılarak, yeni medyanın en çok hangi formatlarda iletimlere potansiyel sunduğuna dair çıkarımlar yapılmıştır.

Anahtar kelimeler: geleneksel medya, canl yayı, yeni medya, internetten canll iletim, Periscope, yurttaş haberciliği, sosyal medya, eski medya formatı, yeni medya formatı 


\section{INTRODUCTION}

Providing the audience with a sense of "being there" has a prominent place within the objectives of using developing technology for both traditional and new media. Throughout the history of traditional media, Electronic News Gathering, Satellite News Gathering and Use of Cellular Networks (3G/4G cameras) have made live broadcast very easy and fast in a way that no one could have imagined before. Moreover, the developing digital technology has provided this opportunity not only to professional reporters but to citizen reporters as well.

In new media, mostly the term "live streaming" has been used to replace the term "live broadcast" in traditional media. Ustream and Livestream platforms, launched in 2007, provided their users a live video opportunity and were used widely on a global scale; however; as a mobile application that enables live streaming with just one click, Periscope has made live streaming a more popular concept in the fields of new media and citizen journalism.

People describing Twitter as a revolution for citizen journalism saw Periscope as a form of revolutionary Twitter with an additional live-video coverage and attributed bigger roles to it in the context of new media, social media and alternative media. Broadcast media, particularly in breaking news coverage, has not been alone on stage for a while. Broadcast media and its professional reporters have been sharing the stage with live streaming applications such as Periscope and millions of users of these applications. So, what does the situation look like in practice and how efficient do the Periscope users use this stage? This assumption was examined by quantitative content analysis method in this research.

After the United States, Turkey is the second most active country to use Periscope in the world. Therefore, it is an important country to examine the effectiveness of Periscope as a new media medium against traditional media. This is why a sample consisting of professional reporters and citizen reporters using Periscope in Turkey was created and the broadcasts of these users had been observed for one month. Each broadcast was coded as a different broadcast type, categorized according to various criteria and statistical results were obtained. Although "broadcast" is a term used mostly in traditional media, it is used throughout this paper as Periscope application itself refers to live streamings of users as "broadcast".

How do the citizen reporters and professional reporters use this live streaming application? Do the audience numbers point to a significant potential? Is Periscope, as a new media medium, being used mostly in old media format or new media format? Can citizen and professional reporters provide answers to journalistic questions during their Periscope broadcasts, in other words can they do reporting or do they broadcast just live? Looking for the answers of these questions, this study aims to contribute to the studies regarding the potential of new media in accessing news and creating an alternative to traditional media in news access.

Meanwhile Twitter, the owner of Periscope, had to change the name of the application in Turkey to "Scope" on March 31, 2017 due to the complaint of a Turkish company. The "Periskop Communications and Production Services" company in Turkey sued Periscope for violating its trademark rights. The court's decision was to halt Periscope. Twitter changed the name of Periscope to keep the availability of its application while announcing that it would continue to seek its rights. However, as the sample study in this paper was carried out in 2016, the application is referred to as "Periscope" not "Scope" throughout the paper.

\section{Live Broadcast}

For broadcast media, "live from scene" has always been a key element to attract big audiences. In early years of TV broadcasting, radio held the advantage of live broadcast. As radio provides only 
audio transmission, breaking news could be broadcast live from the scene through a fast and low-cost operation. However, the advancement in technology changed this situation.

Radio has lost some of its advantage as new technology has made it possible for television to put a live signal into homes almost as quickly and easily as radio does (Barnas \& White, 2010: 193). This is due to the fact that developing technology started offering TV crews big opportunities for live broadcast from the scene. Live broadcast from the scene was such a challenge for TV crews that Boyd described it as an operation on the scale of a military manoeuvre. In times past, even the most basic Outside Broadcast (OB) would tie up crowds of highly paid professionals and tons of expensive equipment (Boyd, 2001: 318). However, as the technology developed, the number of people in crews as well as the size of both equipment and $\mathrm{OB}$ vehicles had become smaller. Especially Electronic News Gathering (ENG) and Satellite News Gathering (SNG) enabled television to grab the advantage of outside broadcast from radio. Live broadcast became faster, easier and more cost effective for television.

ENG, available since mid-1980s thanks to the developing technology, accelerated the outside broadcast capabilities of TV broadcasting in such a way that Higgins described it as the biggest change in news gathering since the invention of wireless. With ENG, pictures in electronic format, smaller tape recorders and players, portable editing equipment for field use, transportation of all equipment in one small truck equipped with a portable microwave transmission system had enabled television stations to broadcast live from a remote location (Higgins, 2007: 15).

ENG technology did not only contribute to outside broadcast but offered great opportunities for inside broadcast as well. The definition of ENG in Wikipedia includes the expression "A broadcast news industry description of television producers, reporters and editors making use of electronic video and audio technologies for gathering and presenting news." (Wikipedia, 2012). This definition emphasizes that ENG had changed the face of each step of TV news production process. However, live from the scene was so important to attract big audiences particularly in breaking news that some definitions of ENG underlined solely this aspect of it. Electronic News Gathering: Television news done on-location (Stephenson, Reese \& Beadle, 2005: 320).

Describing ENG as the biggest change in news gathering since the invention of wireless, Higgins referred to the use of satellites as the next big development. The development of satellite communications technology was the next leap forward in newsgathering, overlapping with the development of ENG (Higgins, 2007: 15). The emergence of communication satellites and their increase in number enabled live broadcast through microwave from locations lacking the capability of live broadcast. This provided TV broadcasters a significant opportunity particularly during international news events. Describing this new situation as no major international conflict can ever now be reported without SNG's use, Higgins emphasizes the concept of being there by saying "sense to the audience of 'being there' is felt the most" (Higgins, 2007: 2).

Sense of being there is not a concept of live from scene era in which live from scene could be performed in a very fast way thanks to ENG and SNG opportunities offered by the developing technology. Emphasis on the sense of "being there" as a concept traces back to the very first years of TV broadcasting. In fact, Spigel calls this concept as a promise which differentiates TV from cinema. Indeed, television -at its most ideal- promised to bring to audiences not merely an illusion of reality as in the cinema, but a sense of "being there", a kind of hyper-realism (Spigel, 1992: 14). The sense of being there, described as a kind of hyper-realism by Spigel, has been an attraction for both traditional media and new media which they seek to turn into an advantage.

Live from the scene being a big attraction for the viewers in breaking news coverage, has become an element of competition especially for news channels. The expression "go live as soon as possible and stay live as long as possible" is a motto for the news channels. This is due to the shift of audience from 
entertainment channels to news channels during breaking news; and the fact that viewers prefer the news channels that broadcast live from the scene while zapping between them in such occasions.

After ENG and SNG, the rise of wireless broadcast transmission made live broadcast possible through cellular network. Modern applications such as hardware and software Internet Protocol encoders/decoders have allowed the use of public $3 \mathrm{G} / 4 \mathrm{G}$ networks to broadcast video and audio (Wikipedia, 2016). Besides, the developing technology now does not provide live broadcast opportunity only to broadcast industry but to citizen journalists as well.

\section{Live Streaming}

The term "live streaming" in new media has become the counterpart of the term "live broadcast" in traditional media. In definitions of "streaming" an emphasis is laid on its meaning of "continuous flow". As an example, Wikipedia defines streaming media as multimedia that is constantly received by and presented to an end-user while being delivered by a provider (Wikipedia, 2017). Rayburn and Hoch, approaching streaming media as a business model and known for their studies on this topic define streaming media as: The shorthand phrase to refer to any audio and video content delivered over a network based on Internet protocols (an "IP network") (Rayburn \& Hoch, 2005: 13).

Satellite News Gathering has provided an important opportunity for 24-hour news channels in terms of live and breaking news coverage. However, developing digital technology and convergence showed its disruptive effect for traditional media in this field as well. Richard Sambrook, a former director of $\mathrm{BBC}$ global news, argues that satellite TV has been overrun by innovative digital technology in news consumption methods. Sambrook points out that the breaking news market is no longer unique, and has been partially replaced by Twitter and Facebook audiences assimilating and distributing information (Sethna, 2015). Live streaming has also taken its place in this field with Periscope and Meerkat applications.

Live streaming became a popular concept in the realms of new media and citizen journalism after the launch of Periscope and Meerkat, however their predecessors emerged in 2007. Both Livestream and Ustream were launched in 2007. David Pearce, a senior staff writer at Wired, points that, before Periscope, Millions used Twitch to watch other people play videogames, YouTube, UStream and a dozen others have tried to make businesses out of live-streaming video but Periscope is like the right platform and the right time (Pearce, 2015). Social media journalist Alastair Reid also reports that livestreaming apps are nothing new but as smartphone cameras and internet connectivity have increased, as have the possibilities to broadcast straight from mobile (Reid, 2015).

\section{Periscope as a Live Streaming Application}

Jeremy Littau, a former journalist and now a researcher in social networks, stated the difference of Periscope and Meerkat from their predecessors as "These apps have added simple, elegant interfaces and social sharing ease to the mix. Regular citizens and everyday reporters alike are now broadcast reporters". Littau points out the big transformation evoked by Meerkat and Periscope by quoting Dan Pfeiffer, former press secretary for President Obama: If 2004 was about Meetup, 2008 was about Facebook, and 2012 was about Twitter, 2016 is going to be about Meerkat (or something just like it) (Littau, 2015). It is possible to include Periscope in Littau's expression "Meerkat or something just like it".

Meerkat and Periscope, with very close launch dates, have been discussed in numerous articles together as revolutionary live streaming applications. Bree Brouwer, specialized in streaming technology, also mentioned Meerkat and Periscope side by side in her article where she discussed applications that made streaming way much easier compared to previous period: "Before, most people who wanted to broadcast live were tethered to their desktop or laptop in front of a webcam. With the introduction of apps such as Meerkat and Periscope, anyone who wants to live stream can do so directly from his or her phone." (Brouwer, 2015). Jeff Howe who is specialized in media innovation 
and coined the term crowdsourcing, embraced this recent technology by mentioning Meerkat and Periscope together as well. While stating that streaming applications like Bambuser had helped spreading information during the Arab Spring and Occupy protests Howe sees "a more real-time, immediacy aspect" in new applications such as Meerkat and Periscope (Lever, 2015).

Whether expressed as the sense of being there or highlighted as an immediacy aspect, the biggest attraction offered by a live streaming application like Periscope is the possibility it provides for outside broadcast through just a single touch on a mobile phone. And this means a great opportunity for primarily citizen reporters. In fact Periscope's emergence story dates back before its acquisition by Twitter and its launch in 2015 which emphasizes citizen journalism. An Iranian enterprenaur Kayvon Beykpour was planning to visit Istanbul in 2013. Just before his visit, Gezi protests took place in Taksim Square and continued for days. The critical question which led Beykpour who was trying to follow the developments from TV news and Twitter was: "What's actually going on outside my hotel? There are probably thousands of people with smartphones and high-speed connections in Taksim Square right now. Why couldn't I see what they are seeing in real time?" (Pearce, 2015). "Seeing or exploring the world through the eyes of somebody else" has become a motto for Periscope, and scholars in the field of communication have been interested in what this motto could offer to both professional journalism and citizen journalism.

\section{What Does Periscope Offer to Journalism?}

What does Periscope mean for professional journalism? What does Periscope offer to citizen journalism? In this section Periscope, as a live streaming application is evaluated within the framework of these questions. It is clear that the situation in which any live streaming application would be highly appealing will be breaking news. Dan Gillmor, who is known for his book and studies on citizen journalism, mentioned this fact in an interview with AFP (Agence France Presse) in the days of the launch of Periscope: "When something newsworthy is happening where it is unexpected, the odds that a professional journalist holding a camera or video camera are small. But the odds that a regular person will be there are close to 100 percent." (Lever, 2015).

Communications strategist Jeremy Porter, describing Twitter as the first broadcast breaking news in text and photo formats, referred to Periscope which provides the same opportunity with live video coverage as the next transformation in social media-based reporting. (Porter, 2015). Owen Williams, a former reporter for TNW (TheNextWeb), described Periscope as being almost like the next-level Twitter, and the world Periscope delivers as a whole new level of the unfiltered world. However, Williams also pointed out the drawbacks of Periscope presenting the scenes and information in an unfiltered way which are supposed to be cut during live broadcast in broadcast media (Williams, 2015). Scenes which could not be broadcast due to broadcasting codes being streamed by citizen reporters on Periscope may be seen as an inconvenience, however in cases of political pressures or broadcast bans in which broadcast media is unable to broadcast certain scenes, Periscope offers an incredible potential in favor of freedom of information.

Some authors, scholars and bloggers made comparison between live streaming of citizen reporters and live broadcast of professional reporters. One of the comparison criteria is interactivity. In such a comparison, interactivity is stated as the main difference between Periscope and a reporter doing a live cross on the scene. Viewers can comment and ask questions and it's findable and sharable in the social media haystack in the way that a TV or online live news channel is not (Public Media Alliance, 2015). Another comparison criteria is the technical capacity of the recording equipment and the professionalism of the people using them. According to Jack Smith, a reporter covering tech business, the best tool to broadcast a protest is a professional camera that records great sound and audio used by a trained cameraperson (Smith, 2015). One other comparison criteria is how much of the presented material is news and how much of it is source material. According to Mic Wright, Former Chief Tech Blogger at The Daily Telegraph, live video of a fire, an explosion or a protest 
isn't the story, it's a catalyst or source material for a story. Wright stated that analysis and thought are required to turn this source material into a news story (Wright, 2015).

Thus, journalist Kyle Jaeger experienced that a streaming video may not always include answers to journalism questions. Watching a live stream of a police chase encountered and broadcast by the Periscope user David Stroup, Jaeger wrote to the user and advised him to interview with someone to learn more however the user could not do more than what he was already doing. So, Jaeger could only find out more about the incident minutes later through an update by Associated Press. Jaeger stated his conclusion about Periscope out of this experience as "It isn't about replacing the press or marginalizing the need for firsthand reporting. It's about bolstering the reach of journalists and media organizations through interactive social media networks. That's what Periscope has to offer" (Jaeger, 2015).

Bild reporter Paul Ronzheimer's coverage of refugee crisis using Periscope is a significant example of what Periscope offers to professional journalists. Paul Ronzheimer travelled with a group of Syrian refugees from the Greek island of Kos across Europe and broadcasted live videos using Periscope. One of the videos was played and replayed more than 90,000 times. For Andy Bull, author of Multimedia Journalism, the true advantage of these broadcasts was the ability of the viewers to comment during the broadcast and the opportunity provided to the refugees for answering the questions of the viewers live and in an unmediated way (Bull, 2017).

\section{Citizen Reporters / Professional Reporters}

One of the criticisms against citizen journalism is the problem of presenting reality in accordance with objectivity and ethical codes due to the absence of any broadcasting codes and responsibilities as a citizen reporter does not have a professional training nor represent a certain organization. Yet, it should be remembered that the journalists having received such professional training and working for such organizations are not exempted of any problems regarding the presentation of reality in accordance with objectivity and ethical codes as well. Therefore, considering the quality of journalism rather than who is performing it would be a more appropriate approach.

Gillmor similarly noted that the right question to ask would be "Who is a journalist?" rather than "What is journalism?" (Gillmor, 2010: 51). Gillmor adopted the same approach regarding citizen journalism and instead of a single definition, he emphasized the potential of contributing to journalism ecosystem which we all have thanks to the Digital Age tools (Gillmor, 2010: 53). Examining OhmyNews.com founded by Oh Yeon Ho who said "Journalists aren't some exotic species, they're everyone who seeks to take new developments, put them into writing, and share them with others." as a case study, Gillmor noted that legal and cultural questions regarding citizen reporting were enormous and expressed his view on the future of journalism by saying "Still, the advantages outweigh the risks." (Gillmor, 2006: 122).

In order to understand applications and platforms such as Periscope, dwelling on the convergence culture composed of both citizen reporters and professional reporters seems like a better option than seeking for contrasts between the two or comparing them on the same level. Observations by both Jenkins and Deuze on convergence culture in which citizen reporters and professional reporters take part side by side, provide a good basis for the theoretical framework of this study which examines how journalists use Periscope in Turkey. This will also be in line with Geiger and Lampien's approach of "calling attention to the tensions that arise around a "coming of age" instead of "calling attention to the familiar trope of "old against new" (Geiger \& Lampinen, 2014: 333).

According to Jenkins, convergence does not depend on any specific delivery mechanism. Rather, convergence represents a paradigm shift - a move from medium-specific content toward content that flows across multiple media channels, toward the increased interdependence of communications systems, toward multiple ways of accessing media content, and toward ever more complex relations 
between top-down corporate media and bottom-up participatory culture (Jenkins, 2006: 243). Fuchs criticized Jenkin's definition of participatory culture for being "a culturalistic understanding of participation" and for ignoring the notion of participatory democracy. Jenkins' definition and use of the term "participatory culture" ignores questions about ownership of platforms/companies, collective decision-making, profit, class and the distribution of material benefits (Fuchs, 2014:103). This study, as a content analysis on how Periscope is used as a live streaming application by citizen reporters and professional reporters, adopted the perspective of a platform where amateurs and professionals are cocreators.

When citizen journalism is considered through the framework of convergence culture, it is seen that professional reporters and engaged citizens co-create a public sphere and according to Deuze who deploys potential strategies for future citizen journalism, convergence from the bottom-up happens as media users are concurrently immersed in multiple media technologies, channels and genres (Deuze, 2009: 259). This is one of the references of new media. Under the title "New ways of representing the world" of a schema listing what new media refers to, Lister, Dovey, Giddings, Grant and Kelly emphasized the immersive nature of new media with the expression "a media which offers new representational possibilities and experiences (immersive virtual environments, screen-based interactive multimedia)" (Lister, et al., 2009: 12).

\section{METHOD}

Content analysis was used as the method of this research. A quantitative content analysis was conducted on the broadcasts by citizen reporters. A one-month period was selected for this analysis: Feb 16 - March 17, 2016. However, the sampling studies started at an earlier date, around early February 2016. Professional reporters to be included in the sample was restricted to the number of followers they had. Journalists with more than 12,000 Periscope followers were observed. 30 journalists were selected this way and they were listed by their follower numbers. TV anchorman Fatih Portakal with 182,758 Periscope followers (3.77 million Twitter followers) ranked first in the list while journalist Metehan Demir with 13,088 Periscope followers ranked last.

However, during the preliminary studies, it was observed that an analysis based solely on the criteria of follower numbers would not be sufficient in revealing Periscope's true potential. This is due to the presence of journalists having large numbers of followers yet not broadcasting on Periscope and journalists using it effectively although they have less followers. Thus, during the preliminary studies which were carried out for shaping the sample, only 7 people from a list of 30 had broadcast on Periscope. This is the reason why professional reporters who do not meet the 12,000 follower criteria but use Periscope regularly as well as accounts which regularly perform citizen journalism on social media during the events with insufficient coverage by the mainstream media in Turkey were also included in the sample. Two citizen reporters who broadcast highly watced live streamings during the most dramatic incident took place within the observation period, the blast in Ankara's Kizılay Square, were also taken into consideration. So, a sample composing of a total of 40 professional and citizen reporter accounts was created and 121 broadcasts by these users in a one-month period (Feb 16March 17, 2016) were included in the research.

Records of these broadcasts were kept including following information: User, Periscope ID, Name of Broadcast, Date, Starting Time, Duration, Number of Live Audience, Number of Replay Audience, Number of Total Audience. Each broadcast was categorized and coded according to the criteria listed on Table 1:

\begin{tabular}{|l|l|}
\hline Broadcast Categories & Explanation \\
\hline By Professional (BP) / By Citizen (BC) & $\begin{array}{l}\text { Is the broadcast streamed by a professional } \\
\text { journalist or a citizen journalist? }\end{array}$ \\
\hline Inside (I) / Outside (O) & $\begin{array}{l}\text { Is the broadcast an inside or an outside } \\
\text { broadcast? }\end{array}$ \\
\hline
\end{tabular}




\begin{tabular}{|l|l|}
\hline News (N) / Non-News (NN) & $\begin{array}{l}\text { Is the broadcast streamed for news purposes or } \\
\text { just to share a particular moment with the } \\
\text { followers? }\end{array}$ \\
\hline $\begin{array}{l}\text { Old Media Format (OM) / New Media Format } \\
\text { (NM) }\end{array}$ & $\begin{array}{l}\text { Is the broadcast in old media format or new } \\
\text { media format? }\end{array}$ \\
\hline Breaking (B) / Non-Breaking (NB) & $\begin{array}{l}\text { Is the broadcast a breaking news story or not? } \\
\text { Breaking with Reporting (R) / Breaking "Just } \\
\text { Live" (JL) }\end{array}$ \\
\begin{tabular}{l} 
without reporting? \\
\hline
\end{tabular}
\end{tabular}

Table 1. Categories of Periscope Broadcasts in the Research Sample

Periscope broadcasts resembling traditional TV broadcasts were coded as "Old Media Format". These included mostly the broadcasts streamed sitting at a table in a studio, as longer forms of news talks or in a room as single commentary and longer form broadcasts. Broadcasts apart from these were coded as "New Media Format". Such broadcasts were usually outside broadcasts in shorter forms, moving formats where reporters move during the broadcast or "just live" broadcasts where reporters demonstrate the scene without giving any information.

Breaking News Broadcasts were further coded as either "Breaking with Reporting (R)" or "Breaking Just Live (JL)". If the user had tried to answer the journalistic questions throughout the breaking news broadcast, then it was coded as "Breaking with Reporting" and in cases where the user simply live streamed, the broadcast was coded as "Breaking Just Live (JL)"

After coding the 121 broadcasts in the sample according to which above mentioned categories they fall into, statistics were obtained such as the audience and duration numbers of different broadcast types, their ratio to the total duration and total audience in the sample and their audience per minute. Therefore, conclusions were drawn regarding how Periscope is used for news purposes in Turkey, the weights and audience numbers of different broadcast types, whether the broadcasts of professional reporters and citizen reporters differentiate in terms of type or not, and if professional reporters have an advantage in audience share compared to citizen reporters.

\section{RESULTS}

Periscope is a live streaming application acquired by Twitter. Therefore, comparing the numbers of Twitter and Periscope followers of the users will give an idea about the interest in Periscope. Table 2 shows Twitter follower numbers of top 30 Periscope user journalists with highest follower numbers as of February 2016 and the total audience obtained by their broadcasts on Periscope within the onemonth observation period.

While these 30 journalists with highest Periscope follower numbers in Turkey have a total of $1,347,023$ followers; the number of Twitter followers of the same journalists is $28,148,000$. Therefore, the total number of Periscope followers of top 30 Periscope user journalists in Turkey equals to $4.8 \%$ of their total Twitter followers. Graph 1 shows the dramatic difference between the potential of reaching audiences on Twitter and Periscope of top 30 Periscope user journalists in Turkey.

23 of the 30 top Periscope user journalists had not streamed any broadcasts on Periscope during the research period. The total audience of other 7 journalist who had broadcast was 70,$126 ; 41,227$ or more than half of which was the audience of Rusen Cakir, the only journalist who broadcast daily among these top 30 Periscope user journalists.

\begin{tabular}{|l|l|l|l|l|}
\hline \multicolumn{1}{|c|}{ User Name } & Periscope ID & $\begin{array}{c}\text { Periscope } \\
\text { Followers }\end{array}$ & $\begin{array}{c}\text { Twitter } \\
\text { Followers }\end{array}$ & $\begin{array}{c}\text { Total Periscope } \\
\text { Audience } \\
\text { During } \\
\text { Observation }\end{array}$ \\
\hline Fatih Portakal & @ fatihportakal & 182,758 & $3,770,000$ & No Broadcast \\
\hline
\end{tabular}

Submit Date: 11.07.2017, Acceptance Date: 16.09.2017, DOI NO: 10.7456/10704100/016

Copyright (C) The Turkish Online Journal of Design, Art and Communication 


\begin{tabular}{|l|l|l|l|l|}
\hline Cuneyt Ozdemir & @cunetyozdemir & 179,900 & $4,370,000$ & 4735 \\
\hline Irfan Degirmenci & @degirmencirfan & 95,027 & $1,280,000$ & No Broadcast \\
\hline Can Dundar & @candundaradasi & 79,002 & $2,610,000$ & No Broadcast \\
\hline Mesut Yar & @mesutyar & 75,228 & $1,570,000$ & No Broadcast \\
\hline Metin Uca & @metinuca & 66,945 & $1,930,000$ & No Broadcast \\
\hline Enver Aysever & @enveraysever2 & 53,315 & $1,050,000$ & 1009 \\
\hline Rusen Cakir & @cakir_rusen & 47,382 & 483,000 & 41227 \\
\hline Emre Uslu & @EmreUslu & 42,532 & 718,000 & No Broadcast \\
\hline Ayse Arman & @AyseArman & 41,059 & $1,700,000$ & No Broadcast \\
\hline Hakan Celik & @hakanchelik & 38,453 & 125,000 & 637 \\
\hline Koray Caliskan & @koraycaliskan & 33,945 & 511,000 & No Broadcast \\
\hline Ahmet Ş1k & @sahmetsahmet & 32,807 & 406,000 & No Broadcast \\
\hline Mirgun Cabas & @MirgunCabas & 32,300 & 654,000 & No Broadcast \\
\hline Nazli Ilicak & @Notredamedesion & 32,029 & $1,380,000$ & 4121 \\
\hline Ismail Saymaz & @ismailsaymaz & 28,953 & 305,000 & 9098 \\
\hline Abbas Guclu & @AbbasGucluTR & 28,132 & 443,000 & 9299 \\
\hline Nevsin Mengu & @nevsinmengu & 27,700 & 180,000 & No Broadcast \\
\hline Erkan Akkus & @erkan_akkus & 27,459 & 124,000 & No Broadcast \\
\hline Ezgi Basaran & @ezgibasaran & 23,852 & 697,000 & No Broadcast \\
\hline Yekta Kopan & @yektakopan & 22,961 & 834,000 & No Broadcast \\
\hline Balcicek Ilter & @Balciceki & 22,457 & 413,000 & No Broadcast \\
\hline Ekrem Dumanli & @EkremDumanli & 21,716 & 651,000 & No Broadcast \\
\hline M. Serdar Kuzuloglu & @mserdark & 19,478 & 412,000 & No Broadcast \\
\hline Tarik Toros & @TarikToros & 18,498 & 343,000 & No Broadcast \\
\hline Gulse Birsel & @gulseyazar & 17,778 & 162,000 & No Broadcast \\
\hline Candas Tolga Isik & @CandasTolga & 15,563 & 294,000 & No Broadcast \\
\hline Cem Seymen & @cemseymen & 13,486 & 105,000 & No Broadcast \\
\hline Ahu Ozyurt & @ahuozyurt & 13,220 & 414,000 & No Broadcast \\
\hline Metehan Demir & @metehan_demir & 13,088 & 214,000 & No Broadcast \\
\hline
\end{tabular}

Table2. Top 30 Periscope User Journalists in Turkey as of Feb 2016 
Total Number of Twitter and Total Number of Periscope

Followers of Top 30 Periscope User Journalists in Turkey as of

Feb 2016

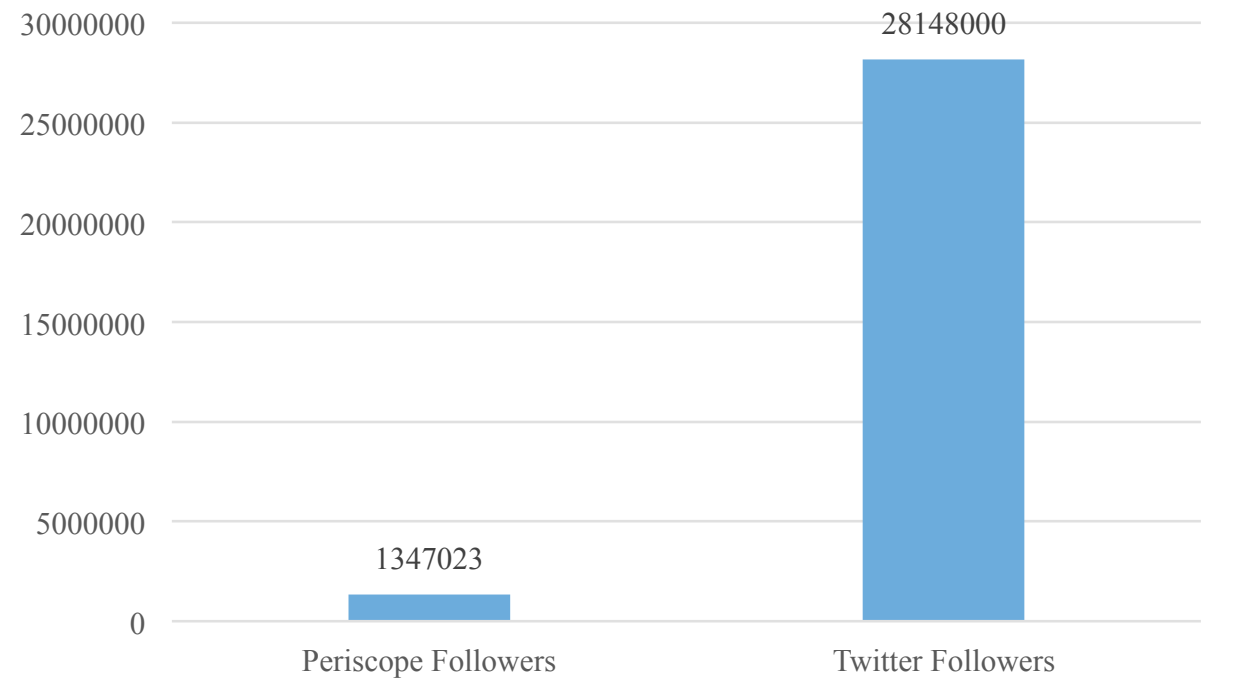

Graph 1. Comparison of Total Periscope and Twitter Follower Numbers of Top 30 Periscope User Journalists

For this very reason, other professional and citizen reporters without high follower numbers yet using Periscope in a regular and active manner had been included in the sample at the beginning. Broadcast number of 17 active users within the 40 -account sample during a period of one-month was 121 . Total duration of these 121 broadcasts was 2605 minutes (43 hours 25 minutes) while the total audience was 228,538 . Audience per broadcast was 1889 , and audience per minute was 88 .

\begin{tabular}{|l|l|l|l|l|}
\hline & $\begin{array}{c}\text { Duration of } \\
\text { Broadcasts (min) }\end{array}$ & Live Audience & Replay Audience & Total Audience \\
\hline Total & 2605 & 161,907 & 66,631 & 228,538 \\
\hline Average & 22 & 1338 & 551 & 1889 \\
\hline
\end{tabular}

Table 3. Total and Average Broadcast Figures of 17 Active Periscope Users in the Sample in Feb 16March 17, 2016

In Table 4, 17 active users are listed from highest to lowest audience per minute.

\begin{tabular}{|l|l|l|l|l|l|}
\hline User Name & Periscope ID & $\begin{array}{l}\text { Periscope } \\
\text { Followers }\end{array}$ & $\begin{array}{l}\text { Total } \\
\text { Duration } \\
\text { of } \\
\text { Broadcasts }\end{array}$ & $\begin{array}{l}\text { Total } \\
\text { Audience } \\
\text { of } \\
\text { Broadcasts }\end{array}$ & $\begin{array}{l}\text { Total } \\
\text { Audience } \\
\text { Per } \\
\text { Minute }\end{array}$ \\
\hline Jhgguu & @Amac_E & 516 & 10 & 28232 & 2823 \\
\hline Cuneyt Ozdemir & @cunetyozdemir & 179900 & 3 & 4735 & 1578 \\
\hline Hakan Ekmen & @Hakanekmen06 & 956 & 37 & 41815 & 1130 \\
\hline Bulent Mumay & @ bulentmumay & 6891 & 29 & 10439 & 360 \\
\hline Ismail Saymaz & @ismailsaymaz & 28953 & 32 & 9098 & 284 \\
\hline Nazli Ilicak & @Notredamedesion & 32029 & 15 & 4121 & 275 \\
\hline Ceyda Karan & @ceydak & 8245 & 29 & 6953 & 240 \\
\hline Capul TV & @capul_tv & 9987 & 160 & 26796 & 167 \\
\hline
\end{tabular}

Submit Date: 11.07.2017, Acceptance Date: 16.09.2017, DOI NO: 10.7456/10704100/016

Copyright (C) The Turkish Online Journal of Design, Art and Communication 


\begin{tabular}{|l|l|l|l|l|l|}
\hline Hakan Celik & @ hakanchelik & 38453 & 4 & 637 & 159 \\
\hline Abbas Guclu & @AbbasGucluTR & 28132 & 63 & 9299 & 148 \\
\hline Enver Aysever & @enveraysever2 & 53315 & 11 & 1009 & 92 \\
\hline Hilmi Hacaloglu & @ hilmihacaloglu & 8512 & 11 & 692 & 63 \\
\hline Ertugrul Albayrak & @ertgrlalbyrk & 9976 & 87 & 5127 & 59 \\
\hline Rusen Cakir & @ cakir_rusen & 47382 & 701 & 41227 & 59 \\
\hline Unsal Unlu & @ unsalunlu & 10143 & 1303 & 35944 & 28 \\
\hline Dokuz8haber & @ dokuz8haber & 4236 & 36 & 853 & 24 \\
\hline Mete Sohtaoglu & @metesohtaoglu & 5151 & 74 & 1493 & 20 \\
\hline
\end{tabular}

Table 4. List of 17 Active Users in the Sample by Total Audience Per Minute

The two users listed in first and third places in Table 4 were citizen reporters who broadcast on Periscope during Kizılay (Ankara) blast, which was the most dramatic incident that took place within the observation period. With follower numbers of 516 and 956 respectively, these two users outscored the rest of the list in terms of audience per minute with the high ratings of their broadcasts during Kizılay blast (with 28,232 and 41,815 audience respectively). Cuneyt Ozdemir, ranking second in the list, is a very popular TV reporter and anchorman in Turkey $(4,370,000$ Twitter followers and 179,900 Periscope followers) however he had broadcast only three times during the observation period. Still, his broadcasts attracted attention on an audience per minute basis.

The top 3 countries in terms of Periscope usage are U.S.A., Turkey and Brazil. (Aslam, 2017). The average audience statistics of both professional and citizen reporters in Turkey, ranking the second country in the world in terms of Periscope usage, do not indicate a big potential as an alternative media. However, when the observed broadcasts in the sample during a one-month period are categorized into By Professional (BP) / By Citizen (BC); Inside (I) / Outside (O); News (N) / NonNews (NN); Breaking (B) / Non-Breaking (NB); Old Media Format (OM) / New Media Format (NM), and the statistics in these categories are evaluated, significant conclusions are drawn regarding the potential offered by Periscope.

\begin{tabular}{|l|l|l|l|l|l|}
\hline Type of Broadcast & $\begin{array}{l}\text { Percentage } \\
\text { in Total } \\
\text { Number of } \\
\text { Broadcasts }\end{array}$ & $\begin{array}{l}\text { Percentage } \\
\text { in Total } \\
\text { Duration } \\
\text { of } \\
\text { Broadcasts }\end{array}$ & $\begin{array}{l}\text { Percentage } \\
\text { in Total } \\
\text { Live } \\
\text { Audience } \\
\text { of } \\
\text { Broadcasts }\end{array}$ & $\begin{array}{l}\text { Percentage } \\
\text { in Total } \\
\text { Replay } \\
\text { Audience } \\
\text { of } \\
\text { Broadcasts }\end{array}$ & $\begin{array}{l}\text { Percentage } \\
\text { in Total } \\
\text { 6Total } \\
\text { Audience" } \\
\text { of } \\
\text { Broadcasts }\end{array}$ \\
\hline By Professional & $88 \%$ & $92 \%$ & $55 \%$ & $63 \%$ & $58 \%$ \\
\hline By Citizen & $12 \%$ & $8 \%$ & $45 \%$ & $37 \%$ & $42 \%$ \\
\hline Inside & $72 \%$ & $86 \%$ & $40 \%$ & $47 \%$ & $42 \%$ \\
\hline Outside & $28 \%$ & $14 \%$ & $60 \%$ & $53 \%$ & $58 \%$ \\
\hline News & $92 \%$ & $99 \%$ & $97 \%$ & $92 \%$ & $95 \%$ \\
\hline Non-News & $8 \%$ & $1 \%$ & $3 \%$ & $8 \%$ & $5 \%$ \\
\hline Breaking & $21 \%$ & $12 \%$ & $55 \%$ & $47 \%$ & $53 \%$ \\
\hline Non-Breaking & $79 \%$ & $88 \%$ & $45 \%$ & $53 \%$ & $47 \%$ \\
\hline Old Media Format & $60 \%$ & $79 \%$ & $32 \%$ & $34 \%$ & $32 \%$ \\
\hline New Media Format & $40 \%$ & $21 \%$ & $68 \%$ & $66 \%$ & $68 \%$ \\
\hline
\end{tabular}

Table 5. Percentage of Categorized Broadcasts in Total Broadcasts in the Sample 
Through the graphics created with the data in Table 5, conclusions could be drawn on which categories have the highest number of streamed broadcasts on Periscope and how much interest they draw in Turkey. First of all, considering the percentages of different categories in total duration of broadcasts in the sample gives us Graph 2.

According to this, $92 \%$ of the total duration of broadcasts in the sample belonged to professional reporters and $8 \%$ to the citizen reporters. $86 \%$ of the total duration of broadcasts was inside broadcast while $14 \%$ was outside broadcast. $99 \%$ of the total duration of broadcasts in the sample was of broadcasts with news purposes and $1 \%$ of non-news broadcasts. $\% 88$ of the total duration of broadcasts in the sample was composed of broadcasts in non-breaking category while $12 \%$ fell in the breaking category. Broadcast Format is considered, it is clear that total duration of broadcasts in old media format weighted $79 \%$ while that of new media format broadcasts was only $21 \%$.

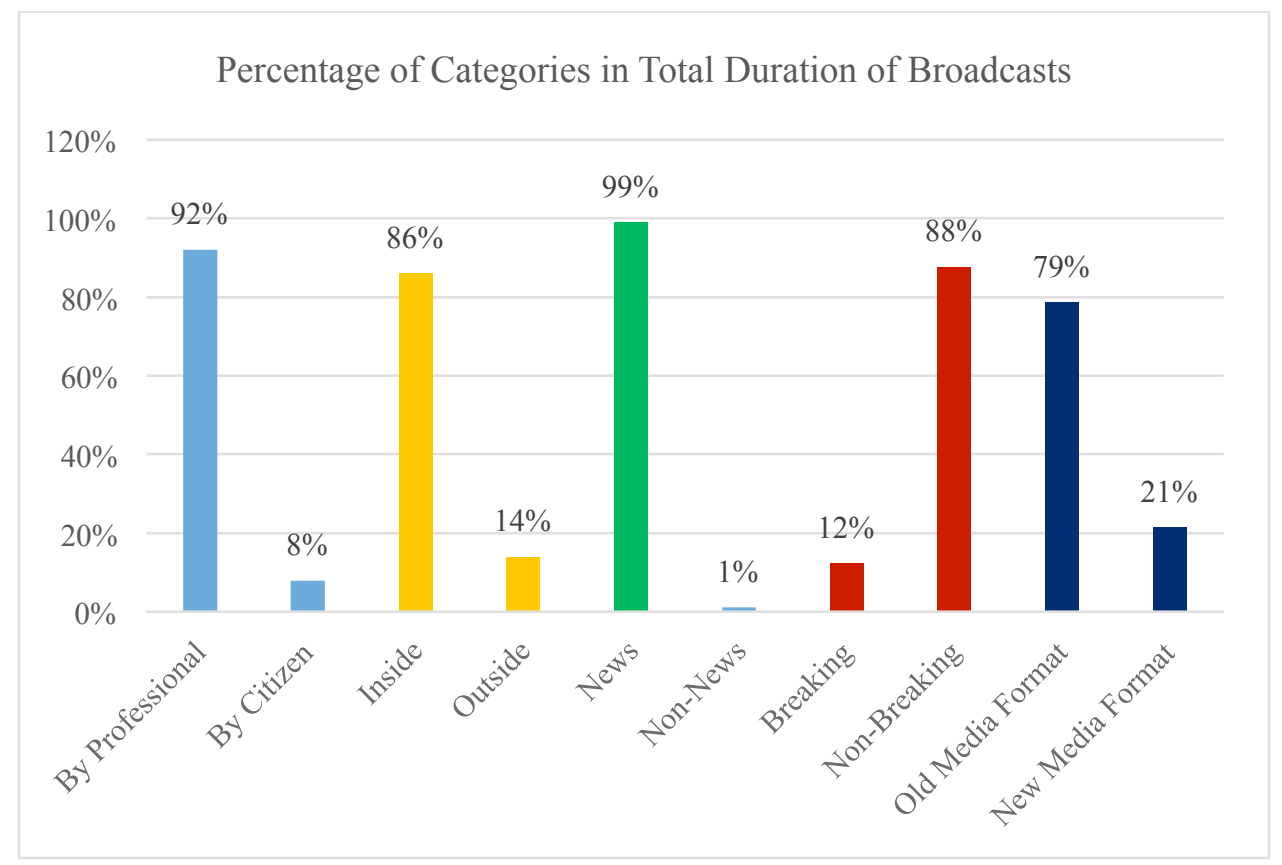

Graph 2. Percentage of Categories in Total Duration of Broadcasts in the Sample

But how much audience did these broadcasts attract? That comparison is given in Graph 3. 


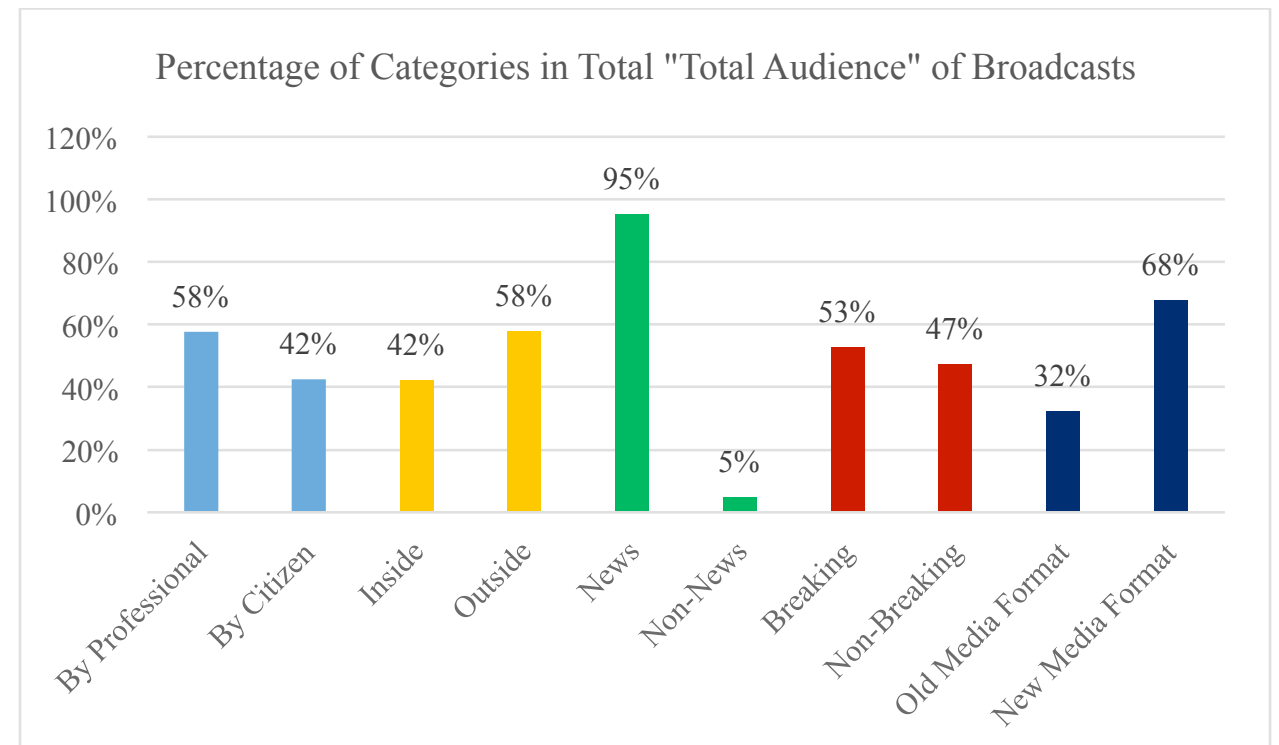

Graph 3. Percentage of Categories in Total "Total Audience" of Broadcasts in the Sample

$58 \%$ of the total audience of broadcasts in the sample in one month belonged to professional reporters and $42 \%$ to citizen reporters. When they are considered in terms of inside broadcast / outside broadcast, the percentages were $42 \%$ and $58 \%$ respectively. $95 \%$ of the audience watched broadcasts with news purposes and 5\% watched non-news broadcasts. Audiences watching breaking news weighted $53 \%$ while $47 \%$ of the total audience watched non-breaking broadcasts. There was much more audience interest in new media format than in old media format. $32 \%$ of the audience watched broadcasts in old media format while $68 \%$ watched new media format broadcasts.

Graphs 2 and 3 indicate clearly that there is a substantial difference between the weights of different broadcast types in total duration of broadcasts and in total audience of broadcasts. Let's take the category by professional / by citizen as an example. Graph 4 shows the percentages of these two categories in total duration of broadcasts and in total audience of broadcasts.

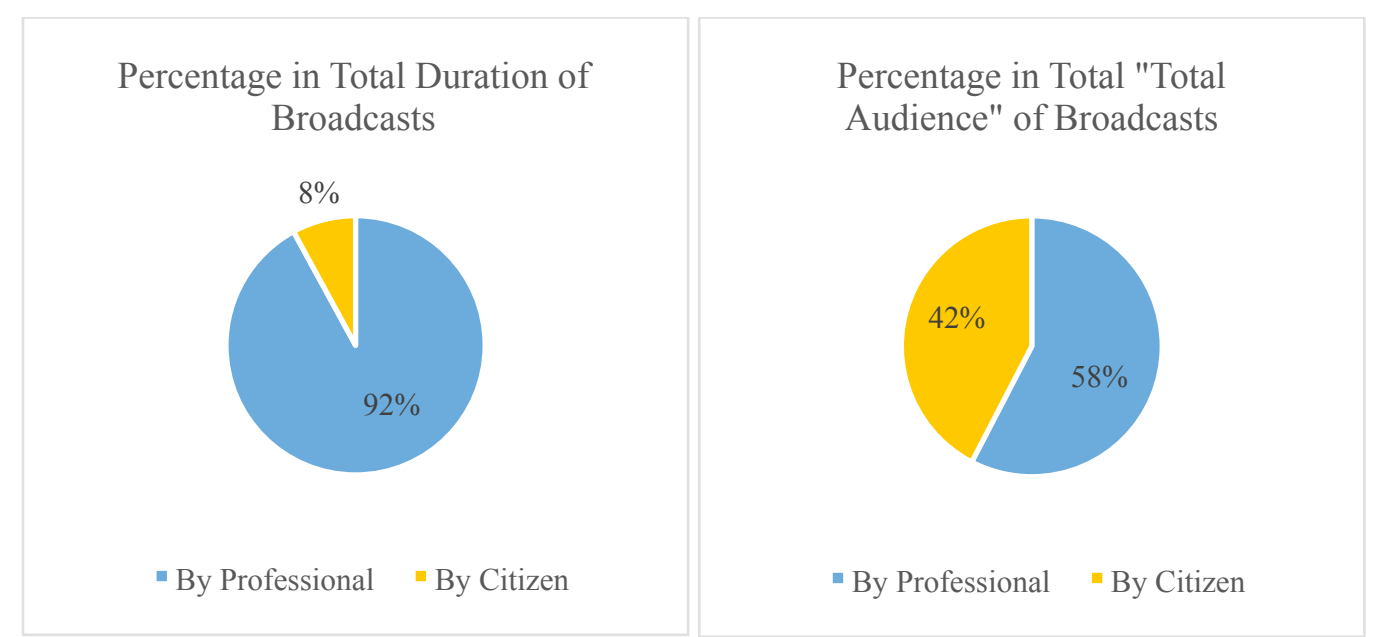

Graph 4. Percentage of "By Professional / By Citizen" Categories in Total Duration and Total "Total Audience" of Broadcasts in the Sample

Professional reporters with $92 \%$ of total duration of broadcasts could only attract $58 \%$ of total audience. On the other hand, citizen reporters with only $8 \%$ of total duration of broadcasts attracted $42 \%$ of total audience. However, two broadcasts during Kizılay (Ankara) blast by two citizen reporters contributed to this significant difference with their high ratings. The percentages, when these two 
broadcasts are excluded, are shown in Graph 5. Citizen reporters with $6 \%$ of total duration of broadcasts could attract $17 \%$ of total audience.

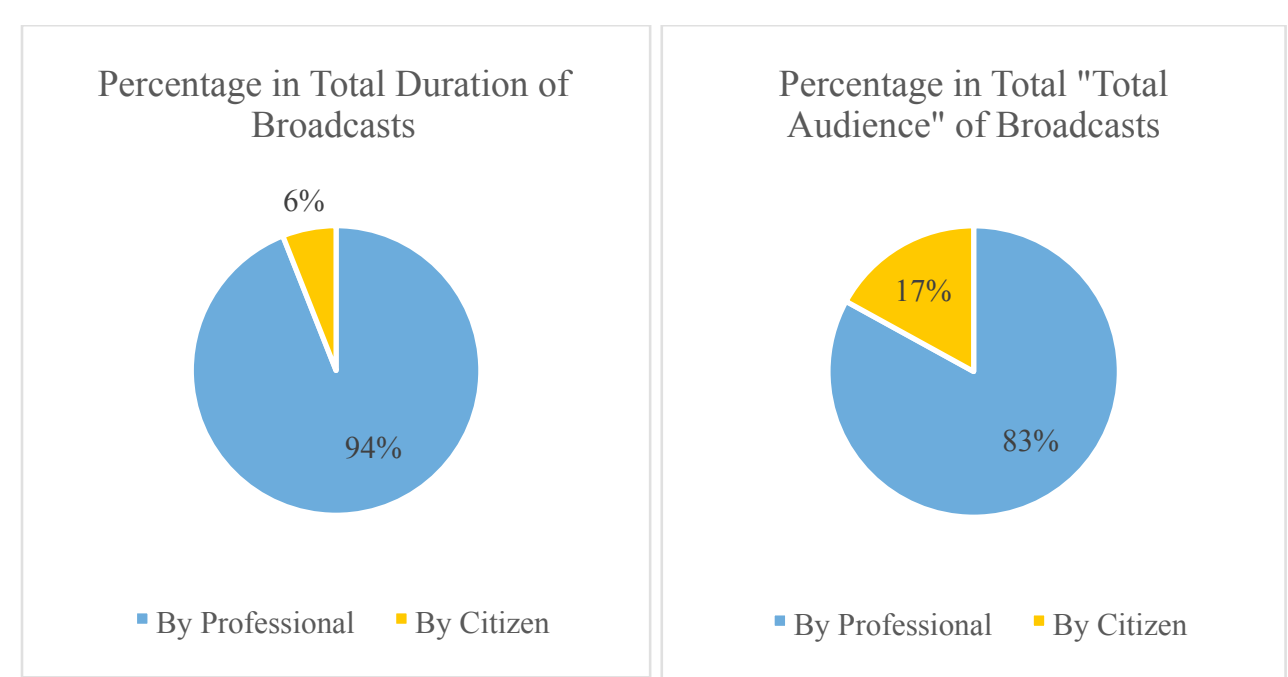

Graph 5. Percentage of "By Professional / By Citizen" Categories in Total Duration and Total "Total Audience" of Broadcasts in the Sample (Excluding Kizılay Blast Broadcasts)

Similar differences occur in other categories as well. Graph 6 serves for comparing the weight of each category in total duration of broadcasts and in total audience of broadcasts.

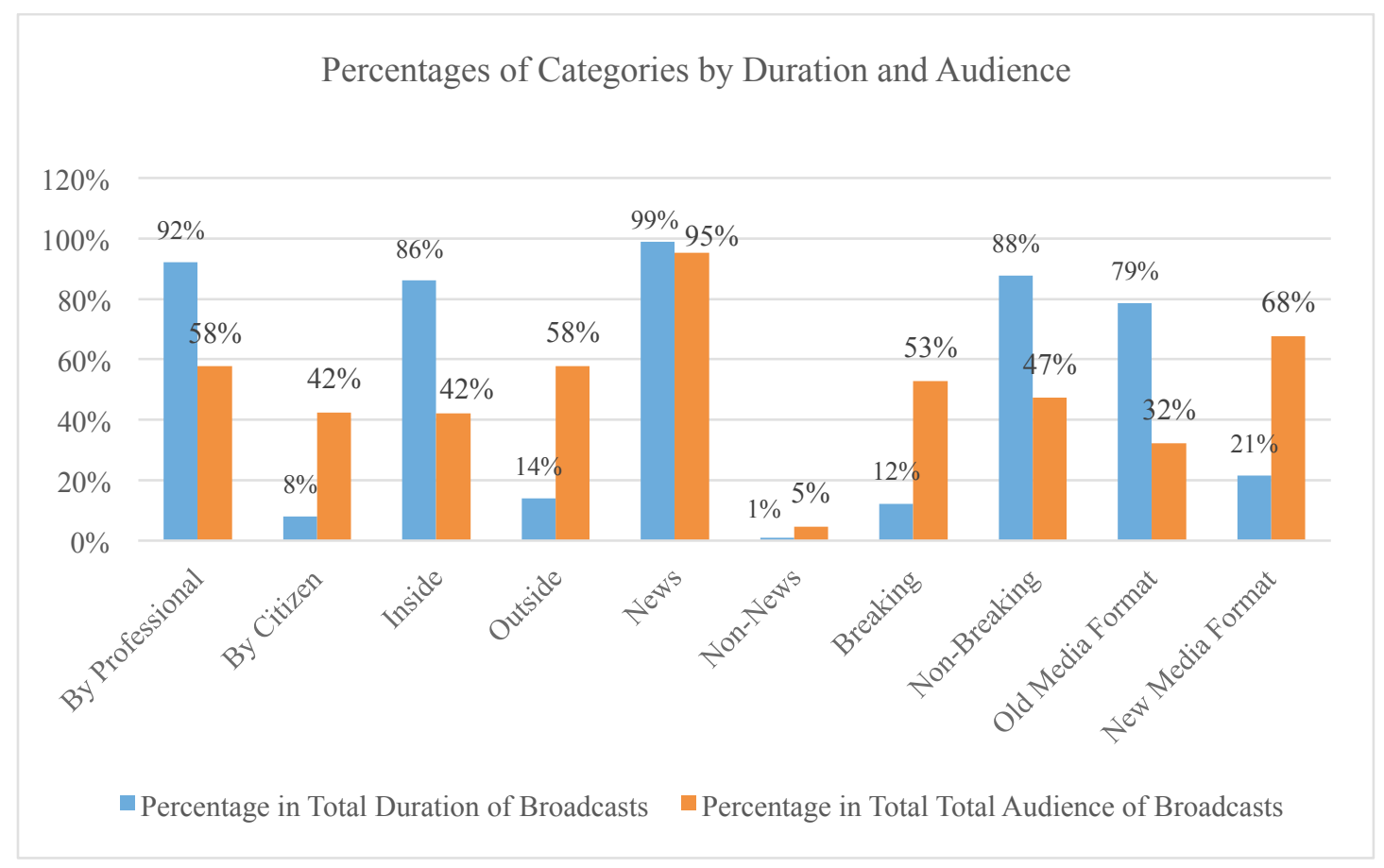

Graph 6. Comparison of Percentages of Categories by Duration and Audience

Graph 6 shows the share of each category in total duration of broadcasts and in total audience on the same row. For example, $86 \%$ of total duration of broadcasts was inside while $14 \%$ was outside but in contrast, the percentage of audience attracted by these categories were $42 \%$ and $58 \%$ respectively. Similarly, breaking broadcasts constituted only $12 \%$ of total duration of broadcasts while being watched by $53 \%$ of total audience. $79 \%$ of total duration of broadcasts comprised of broadcasts in old 
media format however the audience share of these broadcasts were $32 \%$. Broadcasts in new media format received an audience share of $68 \%$.

Especially in breaking news coverage, it becomes even more important whether the broadcast is streamed with or without reporting. It is particularly important for the followers that Periscope users who are covering breaking news seek to answer the journalistic questions, 5W1H. Otherwise it becomes a "just live" broadcast and the audience could find out more about it only through traditional media. This is why the broadcasts categorized as breaking news in the sample were further classified as "Reporting / Just Live".

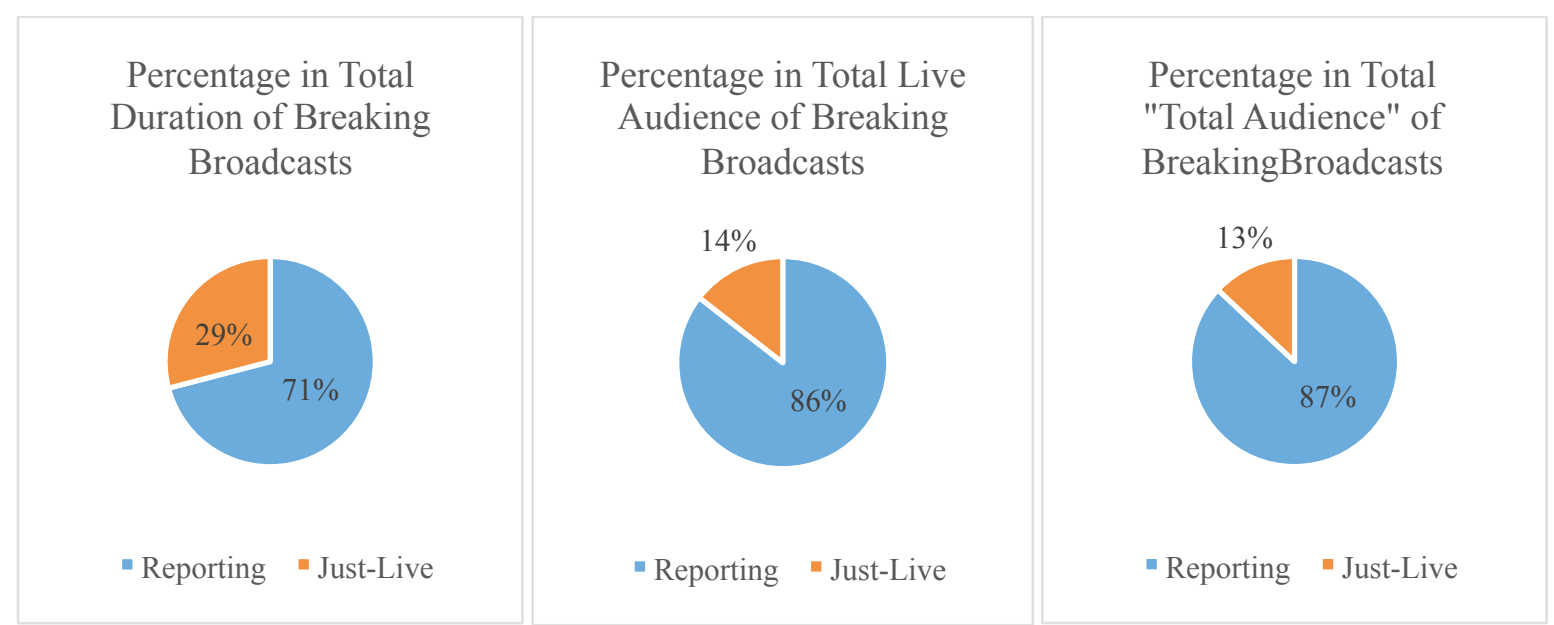

Graph 7. Percentage of "Broadcasts with Reporting" and "Just Live Broadcasts" in Breaking Broadcasts by Duration, Live Audience and Total Audience

As shown in Graph 7, 71\% of the duration of breaking news broadcasts in the sample included reporting. Breaking news broadcasts with reporting received $86 \%$ of live audience and $87 \%$ of total audience which is the total of live and replay audiences.

How much of the broadcasts in the breaking news category was streamed by professional reporters and by citizen reporters, and how many viewers did the breaking news with reporting broadcasts of professional and citizen reporters attract? The answers to these questions are given in Graph 8 and Graph 9 respectively.

\section{Percentages of Breaking Broadcasts with Reporting of Professional and Citizen Reporters in Total Duration of Breaking Broadcasts with Reporting}

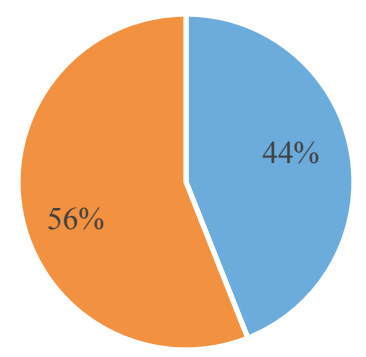

- Breaking Reporting by Professional " Breaking Reporting by Citizen 
Graph 8. Percentages of Duration of Breaking Broadcasts with Reporting of Professional and Citizen Reporters in Total Duration of Breaking Broadcasts with Reporting

$56 \%$ of the Breaking News with Reporting broadcasts were streamed by professional reporters while $44 \%$ were by citizen reporters. While slightly more than half of the broadcasts in this category were streamed by professional reporters, breaking with reporting broadcasts of citizen reporters attracted more viewers $(82 \%)$. It should be noted that the above mentioned two citizen reporters, streaming highly-watched broadcasts during Kizılay (Ankara) blast were effective in these results as well.

\section{Percentages of Audience of Breaking Broadcasts with Reporting of Professional and Citizen Reporters in Total Audience of Breaking Broadcasts with Reporting}

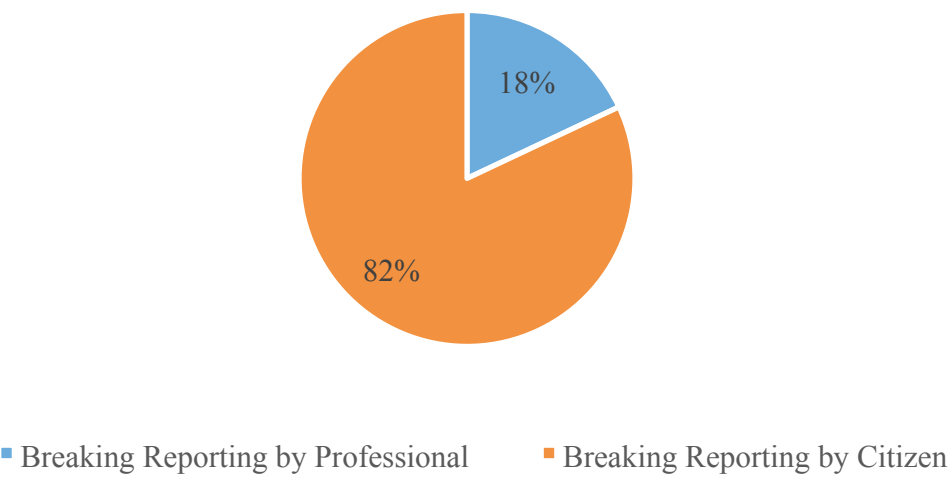

Graph 9. Percentages of Audience of Breaking Broadcasts with Reporting of Professional and Citizen Reporters in Total Audience of Breaking Broadcasts with Reporting

\section{CONCLUSION}

For broadcast media, "sense of being there" or "immediacy aspect" have always been crucial elements to attract big audiences. However broadcast media has not been alone in this field for a while. Digital technology has provided great convenience regarding live from the scene capabilities to new media.

As a popular live streaming application what does Periscope mean for professional journalism? What does Periscope offer to citizen journalism? In this study, a quantitative content analysis was conducted on live streamings of a sample composed of professional and citizen reporters in Turkey which were broadcast through Periscope application in a one-month period then conclusions were drawn regarding the potential that Periscope represents.

Periscope is a live streaming application acquired by Twitter. Therefore, comparing the numbers of Twitter and Periscope followers of the users will give an idea about the interest in Periscope. During the research period, the total number of Periscope followers of top 30 Periscope user journalists in Turkey equaled to $4.8 \%$ of their total Twitter followers. This percentage, at least currently, does not coincide with the bigger role attributed to Periscope by the people who see Twitter as a revolution for citizen journalism and Periscope as a version of this revolution with live-video coverage. In addition, 23 of the 30 top Periscope user journalists had not streamed any broadcasts on Periscope during the research period. These data indicate that when compared to Twitter, Periscope, despite its visual advantage, has a much lower potential in terms of its users' reach to large audiences as well as their willingness to produce content. 
Audience per minute of 121 broadcasts with a total duration of 43 hours and 25 minutes streamed by 17 active users within the 40 -account sample in a one-month period is 88 . This number is unappealing for especially professional reporters who are used to reaching mass audiences, however the total audience of these 121 broadcasts was 228,538. This is in line with Long Tail Theory which argues that the competition between new media and traditional media will proceed in terms of the audience potential of content receiving lower hits yet produced in large numbers, rather than fewer content receiving higher instant "hits".

The average audience statistics of both professional and citizen reporters in Turkey, which ranks second in the world after the U.S. in terms of Periscope usage, did not indicate a big potential as an alternative media. However, when the broadcasts in the sample were categorized into By Professional (BP) / By Citizen (BC); Inside (I) / Outside (O); News (N) / Non-News (NN); Breaking (B) / NonBreaking (NB); Old Media Format (OM) / New Media Format (NM), and the statistics in these categories were evaluated, significant conclusions were drawn regarding the potential offered by Periscope.

The substantial difference between the weights of different broadcast types in total duration of broadcasts and in total audience of broadcasts gave clues about which broadcasts draw more interest. Considered from this aspect and in light of this research it is seen that outside broadcast rather than inside broadcast, news purpose broadcast rather than non-news broadcast, breaking broadcast rather than non-breaking broadcast, and new media format broadcast rather than old media format broadcast attracts more audience. New media format broadcasts, with only $21 \%$ of the total duration of broadcasts in the sample, attracted $68 \%$ of total audience in the sample of this broadcast type. These data point out that in a new media medium, content in new media format receives a much higher rating than traditional media format.

Whether the broadcast is streamed with or without reporting becomes particularly important in breaking news coverage. It is quite important for the followers that Periscope users who are covering breaking news seek to answer the journalistic questions, $5 \mathrm{~W} 1 \mathrm{H}$. Otherwise the audience could only find out more about the incident through traditional media. This research shows that citizen reporters do not lag behind professional reporters in this regard. 56\% of the total breaking broadcasts with reporting in the sample were streamed by professional reporters while $44 \%$ by citizen reporters.

The record in audience per minute belonged to an unfamed Periscope user in the research period. 28,232 people watched the 10-minute broadcast streamed by this Periscope user @Amac_e -having only 516 followers- just after the terror attack in Ankara which killed 37. And this proves the big potential Periscope expresses for such incidents.

In order to understand applications and platforms such as Periscope, dwelling on the convergence culture composed of both citizen reporters and professional reporters seems like a better option than seeking for contrasts between the two or comparing them on the same level. It is seen that this approach, providing basis for the theoretical framework of this study which examines the ways Periscope is used by professional and citizen reporters in Turkey overlaps with the research results.

\section{REFERENCES}

Beadle, M. E., \& Reese, D. E., \& Stephenson, A. R. (2005). Broadcast Announcing Worktext Performing for Radio, Television and Cable. Burlington: Focal Press

Boyd, A. (2001). Broadcast Journalism: Techniques of Radio and Television News. Bodmin: Focal Press

Deuze, M. (2009). The future of citizen journalism. In Stuart Allen, Einar Thorson (Eds.), Citizen Journalism: Global Perspectives (pp.255-264.) New York: Peter Lang. Fuchs, C. (2014). Social Media: a critical introduction. London: SAGE Publications Geiger, R. S., \& Lampinen, A. (2014). Old Against New, or a Coming of Age? Broadcasting 
in an Era of Electronic Media. Journal of Broadcasting \& Electronic Media 58 (3), pp. 333 341. http://dx.doi.org/10.1080/08838151.2014.935855

Gillmor, D. (2010). Mediaactive. San Franscisco: Dan Gillmor

Gillmor, D. (2006). We the Media: Grassroots Journalism by the People For the People. Sebastopol: O'Reilly Media

Higgins, J. (2007). Satellite Newsgathering. Burlington: Focal Press

Jenkins, H. (2006). Convergence Culture: Where Old and New Media Collide. New York: New York University Press

Lister, M., \& Dovey, J., \& Giddings, S., \& Grant, I., \& Kelly, K. (2009). New Media: $\quad$ A $\quad$ Critical Introduction. Oxford: Routledge

Rayburn, D., \& Hoch, M. (2005), The Business of Streaming and Digital Media. Burlington: Focal Press

Spigel, L. (1992). Installing the Television Set: Popular Discourses on Television and Domestic Space, 1948-55. In Lynn Spigel, Denise Mann (eds.), Private Screenings: Television and the Female Consumer (pp.3-41). Minnesota: University of Minnesota Press.

White, T., \& Barnas, F. (2010), Broadcast News: Writing, Reporting and Producing. Burlington: Focal Press

\section{Online}

Aslam, Salman (January 22, 2017). Periscope by the Numbers: Stats, Demographics \& Fun Facts. Omnicore. Retrieved from https://www.omnicoreagency.com/periscope-statistics/ e.t. May 12, 2017

Brouwer, Bree (November 17, 2015). What Live Streaming Means for Content Publishers. Econtentmag. Retrieved from http://www.econtentmag.com/Articles/Column/Screen-Time/WhatLive-Streaming-Means-for-Content-Publishers-107105.htm April 242017 e.t. April 29, 2017

Bull, Andy. How journalists are using Snapchat and Periscope. Retrieved from http://www.andybull.co.uk/masterclasses/masterclass-3-the-journalism-of-now-using-snapchat-andperiscope-for-reporting/how-journalists-are-using-snapchat-and-periscope/ e.t. April 19, 2017

Electronic Newsgathering. (Nov 2012). In Wikipedia. Retrieved from https://en.wikipedia.org/wiki/Electronic news-gathering e.t. December 16, 2016

Jaeger, Kyle (April 13, 2015 ). What Periscope Means for Journalism In The 21st Century. Buzzfeed. Retrieved from http://www.buzzfeed.com/jaegerkyle/what-periscope-means-for-journalism-in-the21st-ce-n7un e.t. May 2, 2017

Lever, Rob (March 29, 2015). New Streaming Apps Could Boost Journalism. AFP. Retrieved from http://news.yahoo.com/streaming-apps-could-boost-citizen-journalism-041709105.html e.t. May 4, 2017

Littau, Jeremy (April 14, 2015). Periscope, Meerkat and the Journalism of Now. Mediashift. Retrieved from http://mediashift.org/2015/04/periscope-meerkat-and-the-journalism-of-now/ e.t. March 27, 2017

Outside Broadcasting. (2016). In Wikipedia. Retrieved from https://en.wikipedia.org/wiki/Outside broadcasting e.t. January 4, 2017

Pearce, David (March 26, 2015). Twitter's Periscope App Lets You Livestream Your World. Wired. Retrieved from http://www.wired.com/2015/03/periscope/ e.t. April 10, 2017 
Porter, Jeremy (March 7, 2015). Periscope and Meerkat: The New 'Twitter' for Reporters. Journalistics. Retrieved from http://blog.journalistics.com/2015/periscope-meerkat-new-twitterreporters/ e.t. May 6, 2017

Reid, Alastair (March 26, 2016). 5 Livestreaming Apps for Journalists and Newsrooms. Journalism.co.uk. Retrieved from https://www.journalism.co.uk/news/5-livestreaming-apps-forjournalists-and-newsrooms/s2/a564597/ e.t. April 15, 2017

Sethna, Razestha (Feb 25, 2015). The Future of Television News. Reuters Institute. Retrieved from http://reutersinstitute.politics.ox.ac.uk/news/future-television-news e.t. February 16, 2017

Smith, Jack (June 4, 2015). TV News Anchors Flock to Periscope in Desperate Attempt to Stay Relevant. Observer. Retrieved from http://observer.com/2015/04/tv-news-anchors-flock-to-periscopein-desperate-attempt-to-stay-relevant/ e.t. April 15, 2017

Streaming Media. (April 2017). In Wikipedia. Retrieved from https://en.wikipedia.org/wiki/Streaming media e.t. April 24, 2017

What on Earth is Periscope and What Does It Mean for Broadcasters? (July 27, 2015). Public Media Alliance. Retrieved from http://publicmediaalliance.org/what-on-earth-is-periscope-and-what-does-itmean-for-broadcasters/ e.t. April 14, 2017

Williams, Owen (March 26, 2015). Periscope and Live Video are Changing the Internet Forever. $T N W$. Retrieved from https:/thenextweb.com/opinion/2015/03/26/periscope-and-live-video-arechanging-the-internet-forever/\#.tnw_OEMd9yUX e.t. May 6, 2017

Wright, Mic (March 30, 2105). Periscope Won't Change the World but It Appeals to Journalists' Vanity. TNW. Retrieved from http://thenextweb.com/opinion/2015/03/30/roll-up-roll-up-to-see-theomnibang/\#gref e.t. April 15, 2017 